\title{
Хроническое физическое перенапряжение опорно-двигательного аппарата у спортсменов
}

\author{
Удк 796.077:612.7+613.73
}

\section{Л. Я. -Г. Шахлина}

Национальный университет физического воспитания и спорта Украины, Киев, Украина

Резюме. Мета. Охарактеризувати етіопатогенетичні фактори розвитку хронічного фізичного перенапруження опорно-рухового апарату, його види, шляхи профілактики. Методи. Аналіз і узагальнення науково-методичної літератури.

Результати. Представлено результати огляду літератури з питань причин, видів пошкоджень структур і функцій опорно-рухового апарату, їхньої профілактики. На основі даних наукової літератури в практиці спортивної медицини і фізіології охарактеризовано стани втоми, перевтоми, перетренованості й хронічного фізичного перенапруження функцій систем організму. Обговорено правомірність терміна «синдром хронічної втоми» і такого стану в практиці спортивного тренування.

Висновки. Обґрунтовано морфофункціонально зміни при хронічних впливах фізичних навантажень, які обумовлюють розвиток мікротравм у структурах опорно-рухового апарату 3 порушенням в пошкоджених ділянках мікроциркуляції, трофічних процесів, підвищуючи при цьому схильність структур опорно-рухового апарату до розвитку гострих травм.

Ключові слова: втома, синдром хронічної втоми, перевтома, перетренованість, хронічне фізичне перенапруження.

Abstract. Data of literature review on causes, types of injuries of locomotor system (LMS) structures and functions and their prevention have been presented. The states of fatigue, over-fatigue, overtraining and chronic physical overexertion of the body system functions have been characterized on the basis of data of sports medicine and physiology literature. Appropriateness of the term «chronic fatigue syndrome» and such state in the practice of athletic training has been discussed.

Aim. To characterize ethiopathogenetic factors of chronic physical overexertion development of locomotor system, its types and means of prevention.

Methods. Analysis and generalization of scientific and methodical literature.

Conclusions. Morphofunctional changes caused by chronic impacts of physical loads that condition the development of microtraumas in locomotor system structures with impairment in damaged areas of microcirculation, trophic processes, thus increasing predisposition of LMS to the development of acute injuries have been substantiated.

The role of chronic impacts of high physical loads in sports preparation practice upon locomotor system structures initially causing the development of microtraumas with impairment in damaged areas of microcirculation, trophic processes and increasing LMS predisposition to acute injury development, has been substantiated.

Keywords: fatigue, chronic fatigue syndrome, over-fatigue, overtraining, chronic physical overexertion.

Постановка проблемы. Анализ последних исследований и публикаций. Общетеоретический интерес к вопросам фризиологии труда и спор- тивной деятельности, специфике адаптации к фризическим нагрузкам имеет большое практическое и социальное значение. Понимание 
фризиологических основ реакций организма на фризические нагрузки, в частности фризиологических механизмов развития процесса утомления дает возможность определять оптимальные нагрузки, способствующие развитию организма, либо предупреждающие патологические состояния при несоответствии величины нагрузки функциональным возможностям организма, что характерно для состояния перетренированности. В литературе ряд авторов считают [1, 10], что высокая утомляемость и постоянное чувство усталости - состояние хронического утомления - характерно для спортсменов в современном спорте высших достижений. С этим трудно согласиться, так как утомление, не проходящее при индивидуальной коррекции тренировочной нагрузки и интервалов отдыха у спортсменов характеризуется не хроническим утомлением, а состоянием переутомления, которое является переходным, предпатологическим [12, 17, 22, 28]. Поэтому, с нашей точки зрения, различная терминология - утомление, хроническое утомление, «синдром хронической усталости» нарушает истинное представления о состоянии организма спортсмена на разных этапах его подготовки и может быть причиной развития перетренированности - патологического состояния [19, 28].

Представленный обзор литературы направлен на научное обоснование фризиологических, переходных и патологических состояний организма спортсменов в практике их спортивной подготовки. Охарактеризована роль механизмов биологической регуляции в развитии перенапряжения функций систем организма в состоянии перетренированности [6, 18, 26].

Цель исследования - охарактеризовать этиопатологические фракторы развития хронического физического перенапряжения опорно-двигательного аппарата, его виды, пути профрилактики.

Методы исследования: анализ и обобщение научно-методической литературы.

Результаты исследования их обсуждение. С увеличением объема инфрормации, об интенсификации всех сторон жизни человека в условиях современного цивилизованного общества проблема утомления - одна из актуальных.

С точки зрения фризиологии утомление - это сложный фризиологический процесс, который проявляется во временном снижении работоспособности в результате выполнения продолжительной или интенсивной нагрузки и восстановлении функций после оптимального интервала отдыха [29].

Процесс утомления сопровождается субъективным ощущением усталости.
Утомление служит сигналом возможного истощения работоспособности организма, предохраняя его от перенапряжения. Однако при этом утомление является фрактором, стимулирующим и мобилизующим функциональные резервы организма, процессы восстановления, повышая работоспособность человека $[1,6,18]$.

Спортивные тренировочные занятия - это процесс систематических воздействий на организм физических упражнений с целью укрепления здоровья, фрормирования и совершенствования двигательных навыков, развития определенных физических и психических качеств, расширения функциональных возможностей организма для достижения высоких спортивных результатов в избранном виде спорта.

Физиологической основой спортивной тренировки является процесс адаптации организма к действию многократных повторений раздражителей - фризических нагрузок, которые вызывают состояние утомления и стимулируют при этом процессы восстановления [29].

По локализации утомления к ведущим системам при выполнении фризических нагрузок любой направленности можно отнести:

- регуляторные системы - рефлекторные и гуморальные механизмы биологической регуляции;

- системы вегетативного обеспечения мышечной деятельности;

- исполнительная система - ОДА.

В работах Г. В. Фольборта - ученика И. П. Павлова, посвятившего более 40 лет изучению фризиологических механизмов процессов утомления и восстановления, было показано, что при развитии утомления изменяется специфрика протекания трофических процессов в органах и тканях. Г. В. Фольборт пришел к заключению, что снижение работоспособности органа в результате его деятельности сопровождается уменьшением функционального потенциала, а его повышение в период восстановления способствует росту работоспособности [29].

В процессе изучения влияния повторных нагрузок автор в одних случаях получал повышение работоспособности, в других - снижение. Причины разных результатов Г. В. Фольборт объяснил тем, что восстановление работоспособности после деятельности органа происходит в две стадии: достижение восстановления и закрепление состояния восстановления. При этом повторные нагрузки, попав в первую стадию восстановления, углубляют процесс утомления, во вторую - повышают работоспособность, по сравнению с исходной. 
Рассмотрев утомление как фризиологический процесс, Г. В. Фольборт и его ученики по рекомендации И. П. Павлова представили проблему утомления и восстановления в виде «правил Фольборта»:

- в органах во время длительной или напряженной деятельности происходят соответствующие трофические изменения, которые снижают их фуннццинальное состояние, что проявляется в развитии процесса утомления;

- трофические изменения, происходящие в органах во время их деятельности, являются основным раздражителем, стимулирующим процессы восстановления;

- чем быстрее (до определенного предела) развивается процесс утомления, тем интенсивнее протекают процессы восстановления;

- при повторных фризических нагрузках в органах могут развиваться два противоположных состояния: при попадании каждой последующей нагрузки в период фрункционального восстановления и закрепления этого состояния работоспособность повышается; если повторные нагрузки попадают на орган, восстановление которого не успело закрепиться, - процесс восстановления ослабевает, развивается хроническое «истощение» [29].

В связи с резким повышением объема и интенсивности тренировочных нагрузок в современном спорте высших достижений отсутствие должного контроля за индивидуальной переносимостью спортсменом предложенных тренером программ подготовки может послужить причиной нарушения функционального состояния спортсмена в виде переутомления, перетренированности и перенапряжения ффункций систем организма.

Переутомление - это переходное (пограничное, предпатологическое) состояние, при котором могут развиваться патологические процессы - заболевания разных органов и систем организма [1, 17].

Состояние переутомления хотя и является крайней степенью утомления, но при этом существенно от него отличается. Если утомление рассматривают как фризиологическую реакцию на фризическую нагрузку, то переутомление представляет собой предпатологическое состояние. Поэтому тренеру необходимо знать признаки предпатологических состояний и уметь их правильно оценивать, для чего своевременная оптимизация тренировочной нагрузки и отдыха может восстановить функциональный потенциал организма спортсмена, восстановив его работоспособность, желание продолжать занятия спортом и добиваться высоких спортивных результатов [6].
По мнению ведущих специалистов в области спортивной медицины, пограничные состояния в последние десятилетия являются одними из главных вопросов, требующих специального рассмотрения, так как к ним должны быть отнесены все состояния, которые не являются противопоказанием к занятиям спортом, не служат основанием для отстранения от них, но могут приобретать со временем признаки заболевания (особенно на фроне напряженных фризических нагрузок), нарушать фрнкции организма, замедлять процессы постнагрузочного восстановления и способствовать возникновению острого и хронического перенапряжения функций отдельных органов и систем организма [17-19].

Исходя из представленных характеристик состояний утомления и переутомления, мы не можем согласиться с термином «хроническое утомление» из представленного выше классического определения, что «утомление - это временное снижение работоспособности...». Поэтому в нашей работе мы будем использовать термины, принятые в практике спортивной медицины «утомление», «переутомление», «перетренированность», «перенапряжение» [10].

По мнению выдающегося специалиста в области спортивной медицины А. Г. Дембо [6], спорт и здоровье - это в какой-то степени синонимы. Однако занятия фризической культурой и спортом несут здоровье только тогда, когда нагрузки соответствуют индивидуальным функциональным возможностям организма спортсмена, соблюдаются режим труда и отдыха, питание. Поэтому в современном спорте несоблюдение выше названных условий может стать причиной тяжелых нарушений здоровья спортсменов.

На Всемирном конгрессе по спортивной медицине в Москве в 1956 г. Людвигом Прокопом (Австрия) был предложен термин «спортивная болезнь». Данная патология в современной спортивной медицине обозначается термином «перетренированность» [17].

Перетренированность - это патологическое состояние организма спортсмена, вызванное прогрессирующим развитием переутомления вследствие чрезмерных фризических и психических нагрузок при недостаточном постнагрузочном отдыхе, что приводит к перенапряжению функций систем организма и, в первую очередь, центральной нервной и эндокринной систем. В результате нарушаются нейрогуморальные механизмы биологической регуляции, что приводит к состоянию перенапряжения функций всех систем организма $[17,26]$.

Хроническое фозическое перенапряжение - это нарушение фрункций органов и систем 
организма вследствие развития состояния перетренированности в ответ на воздействия неадекватных фризических и психических нагрузок функциональным возможностям организма спортсмена [12, 28].

Справедливым является мнение Г. И. Гуськова, В. А. Панкова (2000) «...нельзя забывать, что фризическая активность и спорт - это как лекарство, которое в одних дозах полезно, в других - вредно».

Развитие спорта высших достижений, увеличение количества лиц, занимающихся спортом, интенсивные и длительные физические нагрузки, сопровождающиеся психоэмоциональным напряжением, возрастающие требования, предъявляемые спецификой спортивной специализации к организму спортсмена, повышают потенциальный риск получения травм и развития заболеваний ОДА.

Из всех систем организма под влиянием регулярных занятий спортом наибольшей нагрузке подвергается ОДА. Это биологическая система со сложным строением костных структур скелета, которые вследствие весовой нагрузки (масса тела), тонуса и работы мышц постоянно испытывают механические напряжения [3]. Поэтому благоприятные и неблагоприятные влияния занятий фризической культурой и спортом особенно заметно проявляются на нем.

Недостаточная функциональная подготовленность ОДА является одной из основных причин спортивных травм. Для предотвращения травматизма разработаны специализированные виды разминки, посттренировочные «заминки», научно-методические обоснования построения программ тренировочных занятий с учетом спортивной специализации, квалификации, пола и возраста спортсмена [22, 23].

Неполноценная разминка - неподготовленность ОДА к предстоящим интенсивным и длительным нагрузкам приводит к появлению микротравм и в скелетных мышцах, и в сухожилиях, и в связочном аппарате [13].

Микротравматические повреждения структур ОДА характерны практически для всех спортсменов в спорте высших достижений в результате длительного воздействия фризических нагрузок, специфических для спортивной специализации. Обычно незначительные микроповреждения не вызывают выраженных болевых ощущений, на которые спортсмен не обращает внимание, и продолжают спортивную подготовку, участвует в соревнованиях.

Однако в участке микротравм, например мышц, сухожилий в поврежденных участках в результате микронадрывов нарушается микроциркуляция, в результате уменьшается доставка тканям с кровью питательных веществ и кислорода, в участках микротравматических повреждений развивается гипоксия с последующими дистрофрическими и дегенеративными нарушениями поврежденных участков, которые со временем возмещаются соединительнотканными структурами, снижая эластичность и механическую прочность участка повреждения, повышая при этом предрасположенность тканей с микротравмами к более серьезным повреждениям при несоответствующих фризических нагрузках [8, 32].

Причинами повреждений ОДА могут быть внешние и внутренние фракторы.

К Внешним фоктторам преимущественно относятся специфика вида спорта, включая условия тренировочных занятий и мест проведения соревнований, нарушение принципов и методики обучения (несоответствие сложности упражнений уровню подготовленности спортсмена, неадекватное количество повторений, недостаточная разминка), качество питания, несоответствие режима работы и отдыха, отсутствие систематического медицинского контроля [14, 23].

Внутренними фокторами являются чрезмерные и продолжительные напряжения систем организма при фризических нагрузках: структурно-функциональные нарушения ОДА, в частности костной ткани, в виде микротравм и заболеваний, возраст и пол спортсмена [8, 15].

Профрилактика травматизма в спорте - одна из важнейших задач тренера. Знание причин, прогноз возможных ситуаций, приводящих к травмам, принятие соответствующих мер - все это характеризует профессиональный уровень тренера [23, 27].

Причиной травм в спорте является также недостаточное медицинское сопровождение подготовки спортсменов. Это и недостатки врачебного отбора, и преждевременный допуск к тренировочному процессу либо участию в соревнованиях после перенесенных заболеваний или травм, редко проводимые врачебно-педагогические наблюдения.

Хронические и острые повреждения структур ОДА в спорте - результат несоответствия фризических нагрузок функциональным возможностям данной системы [1, 14, 18].

Итогом хронического травмирующего воздействия на ткани при его силе, не превышающей прочности соответствующей структуры ОДА, являются хронические заболевания.

Ocmрые повреждения ОДА у спортсменов - следствие сиюминутного травмирующего 
воздействия, сила которого превышает прочность ткани. В результате нарушается анатомическая целостность ткани или органа. При острых травмах причинами в основном являются внешние фракторы [12,14].

Хроническое фризическое перенапряжение ОДА у спортсменов может проявляться во всех его структурах:

Перенапряжение структур опорно-двигательного аппарата Мышцы Сухожилия Суставной хрящ Костная ткань

При систематических занятиях фризической культурой и спортом на структуры ОДА, в частности на мышцы и миоэнтезический аппарат (участок перехода мышцы в сухожилие, сухожилия, зона их крепления к надкостнице и кости, опорный аппарат мышцы - ее сарколемма, фрасция), приходится большая нагрузка. Они систематически подвергаются давлению, напряжению, растяжению, сотрясению. При оптимальных сочетаниях нагрузки и отдыха адаптация к такому режиму проявляется в структурных и функциональных изменениях, повышая прочность этих тканей и обеспечивая возможность спортсмену выдерживать большие нагрузки [14].

При неадекватности нагрузки по величине или направленности функциональным возможностям организма спортсмена адаптационные морфоорункциональные изменения в структурах ОДА отстают от силы воздействий, которым они подвергаются. Процессы физиологической регенерации в тканях изменяются, что проявляется в нарушениях обмена веществ, биохимических реакций, развитии дистрофических перерождений и структурных повреждений клеток, а порой и их разрушении. Хроническое физическое перенапряжение ОДА сопровождается вначале бессимптомно протекающими микротравмами с последующим развитием хронических заболеваний структур ОДА и развитием механических повреждений на фоне дегенеративных изменений ткани [12, 13].

\section{Хроническое физическое перенапряжение скелетных мышц}

Миалгия (миозит) - это патологическое состояние, основным проявлением которого является боль в мышцах, несущих основную нагрузку в тренировочном процессе, особенно в начальный период подготовки.

Многие спортсмены в состоянии перетренированности ощущают боль в мышцах. Однако поскольку такое состояние привычно для лиц, занимающихся спортом, оно воспринимается спортсменами и тренером как обычное физиологическое состояние, которое не требует обращения по этому поводу к спортивному врачу. Тренировочные и соревновательные нагрузки продолжаются [12, 19].

Мышечная боль может быть ноющего характера либо в виде периодических «прострелов» и проявляется вначале только во время тренировочной нагрузки, а затем и в состоянии покоя. Такое состояние сопровождается снижением эластичности мышц, силы их сокращений, ухудшением фризической работоспособности [12, 16, 21].

Причиной миалгии могут быть морфологические изменения мышечных волокон в результате микроразрывов плазмолеммы и мелких кровеносных сосудов при повторяющихся эксцентрических сокращениях мышц, обусловливающих их удлинение. Такие микротравмы опорных структур мышечных волокон (плазмолеммы) локализуются в области брюшка мышцы либо в области ее перехода в сухожилие $[12,20]$. В этих областях может наблюдаться некоторая отечность, что связано с притоком жидкости через участки повреждения. При пальпации мышца болезненна, особенно в области уплотненных мышечных волокон.

Причиной миалгии может быть и токсическое воздействие метаболитов, прежде всего молочной кислоты на болевые рецепторы мышц, находящихся в состоянии перенапряжения [19].

Микротравмы при эксцентрических сокращениях могут сопровождаться воспалительными (миозит) и дегенеративными изменениями в мышцах. Спустя 2-3 нед. бо́льшая часть повреждений устраняется в результате регенерации поврежденных участков мышечных волокон. В скелетной мышце постоянно происходит физиологическая регенерация - обновление мышечных волокон. При этом клетки-сателлиты вступают в циклы пролиферации с последующей дифрференцировкой в миобласты и их включением в состав мышечных волокон [5, 20].

По мнению Р. Мохана и соавт., важной причиной развития перенапряжения скелетных мышц является замедление процессов восстановления запасов гликогена в них в результате хронического микротравмирования. В поврежденных мышечных волокнах снижается способность к экстракции глюкозы из крови для ресинтеза в них гликогена. В связи с этим после выполнения продолжительных фризических нагрузок запасы гликогена истощаются, работоспособность снижается [21]. 
Увеличение тренировочной нагрузки для спортсмена после острой миалгии должно соответствовать принципам постепенности и систематичности с использованием тейповых повязок на область поврежденных мышц.

Острый мышечный спазм - патологическое состояние, характеризующееся внезапным непроизвольным сокращением мышц и сопровождающееся острой судорожной болью. Бывает различным по локализации, интенсивности, продолжительности и имеет приступообразный характер.

По мнению специалистов, четких клинических критериев различий острого спазма мышц от разных видов судорог нет (спазм - от греч. spasmos - судорога). При пальпации мышца болезненна, определяются отдельные уплотненные пучки мышечных волокон. Развитие острого мышечного спазма наблюдается при длительном профрессиональном напряжении (балерин, спортсменов), он может продолжаться до трех и более минут [17, 18].

Причины острого тонического сокращения мышц - увеличение определенного вида физических нагрузок, выполнение непривычных упражнений, неполноценная разминка, переохлаждение.

Спазм мышцы, а именно нарушение мышечного расслабления, является одним из признаков ее переутомления, что объясняется нарушением ресинтеза АТФ вследствие накопления метаболитов в утомленной мышце, угнетающих гликолитические и окислительные процессы, что ведет к снижению содержания АТФ и КрФ, вследствие чего «кальциевый насос» не откачивает ионы кальция в кальциевы цистерны ретикулума, концентрация ионов $\mathrm{Ca}^{2+}$ в области миофибрилл остается высокой, головки миозиновых мостиков оказываются устойчиво соединенными с миозином, мышечные волокна находятся в состоянии длительного сокращения - «контрактуры» [20]. При остром мышечном спазме процесс обратим.

Миогелоз - патологическое состояние, являющееся следствием хронического фризического перенапряжения мышц, что проявляется в большей выраженности дистрофрических изменений в мышце. Нарушение белкового обмена в мышце при ее перенапряжении сопровождается фризическим и морфологическим изменениями белка. В результате извращенного его синтеза в тканях начинают изменяться белковые структуры, нарушается кровообращение в мышцах. В результате отдельные мышечные волокна частично подвергаются гиалиновому перерождению [16, 17, 21].

Для миогелоза характерно появление в мышцах небольших узловатых уплотнений, болез- ненных при пальпации, снижение эластичности и ухудшение способности к расслаблению, нарушение координации движений. При коррекции тренировочной нагрузки и надлежащем медицинском сопровождении спортсмена с такой патологией процесс миогелоза может быть частично обратим [17, 18].

Миофиброз - патологическое состояние, которое развивается в мышцах при продолжении тренировочных и соревновательных нагрузок, усугубляющих состояние перенапряжения нервно-мышечной системы спортсмена. В мышцах более выражен дистрофический процесс, фризиологическая регенерация мышечных волокон нарушена, что проявляется в разрушении миофибрилл и их замещении соединительной тканью [1, 8]. Развивается миофиброз. В мышцах боль постоянна и более выражена по сравнению с миогелозом. Процесс замещения мышечной ткани соединительной необратим и компенсируется гипертрофией неизмененных мышечных волокон. В результате выраженное снижение мышечной силы и атрофрия мышц не проявляются. Однако нарушение эластичности мышц ограничивает подвижность в суставах, затруднена способность к их расслаблению, усиливается болезненность при выполнении упражнений с эксцентрическими сокращениями мышц, что иногда сопровождается осложнениями в виде надрывов и разрывов мышц. 20].

Миофиброз - необратимое состояние [16,

Острые повреждения мыши. Закрытые сиюминутные (острые) травмы мышц - типичная спортивная травма, которая проявляется в частичном или полном разрыве мышечных волокон с повреждением ее соединительных структур, кровеносных сосудов, что сопровождается внутримышечной или межмышечной гематомой, резкой болью в области травмы, «хрустом» во время разрыва [12].

По мнению В. Н. Левенца [13], общепринятый термин «растяжение» мышцы - неправильный, так как в силу эластичности мышечное волокно при растяжении если не рвется, то возвращается в свое исходное состояние (первоначальная длина). Разрыв мышечных волокон происходит, если травмирующий фрактор превышает прочность мышечных структур. Поэтому правильнее говорить о частичном либо полном разрыве мышцы. Разрывы мышечных волокон чаще происходят вблизи мышечно-сухожильного соединения, реже - в области сухожильно-костного.

Результаты клинических наблюдений подтверждают, что разрыв мышцы является ре- 
зультатом форсированного ее растяжения (пассивного либо активного) при недостаточной разминке, переохлаждении, т. е. это результат неподготовленности мышцы к применяемым фризическим нагрузкам либо при силе воздействия, превышающей биомеханически допустимую.

Повреждение непосредственно самой мышцы наблюдается намного реже по сравнению с ее повреждением на участке перехода в сухожилие либо сухожилия на кость [12-14].

Наиболее частые разрывы мышцы на участке перехода в сухожилие может быть объяснено развитием дегенеративных изменений сухожилия в этой области. Причиной таких острых мышечных травм является состояние перетренированности с развитием перенапряжения мышц [30].

Меры профилактики перенапряжения мышц, которое проявляется в виде миалгии, острого мышечного спазма, миогелоза, миофиброза, разрыва мышц - оптимальные тренировочные и соревновательные нагрузки, соответствующие подготовленности спортсмена, полноценная разминка, снижение нагрузки при первых признаках перенапряжения мышц, массаж и самомассаж с использованием мазей и гелей (по рекомендации врача), улучшающих кровообращение и обмен веществ в мышцах в период постнагрузочного восстановления $[1,6]$.

\section{Хроническое физическое перенапряжение сухожилий у спортсменов}

К хроническим оризическим перенапряжениям сухожилий относятся:

- тендинит - патологический процесс, развивающийся в самом сухожилии;

- энтезопатия - патологический процесс, развивающийся в местах прикрепления сухожилий и связок к костным структурам;

- паратеонит - заболевание сухожильных влагалищ [13].

Тендинит - заболевание самого сухожилия вследствие длительного хронического перенапряжения, развития в нем асептического (реактивного) воспаления и дегенеративных изменений.

Факторы, провоцирующие развитие заболевания:

- несоответствие величины либо направленности нагрузки фрункциональным возможностям организма спортсмена;

- недостаточная разминка;

- неблагоприятные климатические условия в процессе тренировочных занятий или соревнований;
- несоответствующая экипировка;

- преждевременное возобновление тренировочных или соревновательных нагрузок после перенесенных травм или болезней.

Тендинит ахиллова (пяточного) сухожилия. Название «ахиллово сухожилие» происходит от имени героя древнегреческой мифологии. Когда Ахилл был ребенком, мать окунула его в волшебную воду. Все его тело стало неуязвимым, кроме пятки, за которую мать держала его. Ахилл погиб в Троянской войне после попадания стрелы именно в эту пятку. «Ахиллесова пята» означает, что у человека всегда есть какое-то уязвимое место.

Согласно Международной анатомической номенклатуре (INA), ахиллово сухожилие носит название «пяточное» [13].

Ахиллово (пяточное) сухожилие - сухожилие трехглавой мышцы голени. Оно самое крупное в организме, образуется из сухожилий медиальной и латеральной головок икроножной и камбаловидной мышц и прикрепляется к задней поверхности пяточной кости.

Васкуляризацию ахиллова сухожилия обеспечивают ветви задней большеберцовой и малоберцовой артерий. Специалисты считают, что участок сухожилия выше на 2-6 см от места прикрепления к пяточной кости характеризуется ограниченной васкуляризацией и именно эта зона подвергается повреждениям при длительных напряженных фризических нагрузках [12].

Структурно-фрункциональная единица - трехглавая мышца - ахиллово сухожилие спортсмена подвергаются постоянным воздействиям растяжений мышц и усталостным повреждениям. Между пучками коллагеновых волокон сухожилия расположены ряды сухожильных клеток фиброцитов, сосуды и нервные волокна. При повреждении сухожилия активированные фиброциты и фрибробласты синтезируют коллаген для формирования новых волокон [5].

Области миосухожильного соединения чаще повреждаются у молодых людей, а разрывы в области прикрепления сухожилия к пяточной кости чаще наблюдаются у людей среднего возраста (старше 30 лет) из-за снижения эластичности в результате дегенеративных изменений. Надрывам или разрыву сухожилий обычно предшествуют тендинит, паратеонит $[12,13]$.

Причинами развития тендинита ахиллова сухожилия являются:

- резкие изменения величины или направленности тренировочной нагрузки (добавление спринтерских дистанций в тренировочное занятие); 
- бег по твердому покрытию;

- бег по гористой местности;

- неудобная спортивная обувь;

- большая тренировочная нагрузка (беговая, прыжковая) после длительного перерыва;

- тренировочные занятия в условиях низких температур $[17,19]$.

Симптомы. Основным симптомом является боль в области ахиллова сухожилия после беговой (прыжковой) нагрузки, прекращающаяся в период отдыха. Отсутствие коррекции нагрузки может вызывать:

- усиление боли во время фризической нагрузки с последующим ограничением движений;

- отечность сухожилия;

- его болезненность при пальпации;

- крепитация в области сухожилия при движениях.

Повреждения ахиллова сухожилия, в частности микронадрывы, надрывы или разрывы, случаются у спортсменов довольно часто, особенно у гимнастов, акробатов, легкоатлетов, баскетболистов, фрутболистов $[13,18]$.

Надрывы и разрывы сухожилия происходят в момент резкого и сильного сокращения трехглавой мышцы голени. Нарушение эластичности мышцы повышает риск ее надрывов, заболеваний мышечно-сухожильных соединений, возникновения тендинита.

Клинические наблюдения, особенно после оперативного лечения повреждений ахиллова сухожилия свидетельствуют, что в результате высоких тренировочных и соревновательных нагрузок у спортсменов развивается синдром перетренированности, что проявляется в хроническом фризическом перенапряжении, в частности ахиллова сухожилия, и сопровождается микротравмами, нарушением в поврежденных участках микроциркуляции с последующими дистрофичческими и дегенеративными изменениями сухожилия. Морфологически определяются участки некротической и грануляционной ткани сухожилия, что клинически проявляется локальным отеком, тугоподвижностью и резкой болью при пальпации $[13,31]$.

Следовательно, перенапряжение ОДА и развитие в его структурах, прежде всего в мышцах и сухожилиях, микроповреждений с сопутствующим нарушением в участках механического повреждения микроциркуляции, развитием дегенеративно-дистрофических и некротических изменений снижает эластичность этих структур, их механическую прочность, что предрасполагает к частичному или полному их разрыву [12, 14].

\section{Профилактика травм ахиллова сухожилия}

Просиилактические мероприятия должны состоять в следующем:

- соизмерение тренировочных нагрузок, их направленности функциональным возможностям организма спортсмена с учетом его возраста, специализации и квалификации;

- широкое использование в тренировочном процессе упражнений на растягивание для повышения эластичности мышц и сухожилий, уменьшение амплитуды движений для снятия их напряжения после тренировочных и соревновательных нагрузок;

- полноценная разминка;

- исключение переохлаждения перед началом фризических нагрузок;

- ограничение бега по твердому или наклонному тренировочному покрытию (быстрый подъем по лестнице);

- замена неудобной спортивной обуви на подходящую;

- своевременное обращение к спортивному врачу при первых появлениях болевых симптомов в области ахиллова сухожилия $[12,13]$;

- в период послеоперационной реабилитации через 3 дня после иммобилизации назначают раннюю мобилизацию в виде изометрических и изотонических движений без напряжений (например, на аппарате REV-9000 с дозированной компьютерной программой для растягивания) для восстановления эластичности поврежденной ткани и ее прочности, в частности, послеоперационной рубцовой ткани для обеспечения возможности при возвращении спортсмена к тренировочным нагрузкам выполнять необходимые для соответствующей спортивной специализации упражнений с надлежащей амплитудой, что одновременно послужит и просрилактикой возможных новых повреждений $[1,13]$.

\section{Хроническое перенапряжение костной ткани}

Костная ткань - метаболически активная структура организма, непрерывно развивающаяся и обновляющаяся. В ней постоянно протекают процессы разрушения старой кости - резорбция и образование новой - ремоделирование. Ежегодно реконструируется до $10 \%$ костной ткани скелета взрослого человека. В возрасте до 20 лет образование кости преобладает над костной резорбцией, к 25 годам - формируется пик развития костной массы. Наибольший прирост костной ткани наблюдается в возрасте 10-15 
лет, т. е. в период полового созревания человека. Основная структура костной ткани наследственно предопределена, но ее масса и структура во многом зависят от главных фракторов - сбалансированного питания, характера физических нагрузок, гомеостаза, активности половых гормонов (протекторов костной ткани) [11, 15, 24].

Профрессионализация и коммерциализация современного спорта поддерживают тенденцию к увеличению тренировочных нагрузок. Отсутствие должного квалифицированного медицинского контроля за переносимостью спортсменами больших объемов выполняемой работы не способствует их здоровью, поэтому занятия спортом, как правило, сопровождаются острым и хроническим перенапряжением одной или нескольких фрункциональных систем, в том числе и ОДА [27].

Физические нагрузки в спорте требуют надежной механической поддержки тела спортсмена, т. е. полноценного структурно-функционального состояния костной ткани скелета.

Известно, что костная ткань выполняет в организме три основные функции: механическую (прочность костной ткани в составе ОДА - важнейшее условие при локомоциях); защитную защита жизненно важных внутренних органов (кости черепа, грудной клетки, таза); сама кость является вместилищем для костного мозга, осуществляющего гемопоэтическую и иммунную функции; метаболическую - костная ткань является депо кальция и фосфора в организме, поддерживает в нем их гомеостаз [11].

Еще в 1892 г. Дж. Вольф установил, что под влиянием механических нагрузок изменяется структура кости: в области бо́льшей нагрузки преобладает ее орормирование, в области меньшей - резорбция. Этот принцип в медицине известен как закон Вольфа [2].

А. Т. Бруско и соавт. [3] показали, что в процессе обычной ходьбы кость человека подвергается переменным нагрузкам продольного сжатия-растяжения, что сопровождается упругой деформацией и вызывает физиологические изменения микроциркуляторного обеспечения трофиких и метаболических процессов в костной ткани.

В процессе жизнедеятельности костная ткань адаптируется к новым условиям фризических нагрузок, костная структура перестраивается, поэтому ОДА способен выдерживать большие физические нагрузки. Изменение структуры костей и тонуса мышц в различных условиях двигательной активности называется функциональной перестройкой, которая бывает фризиологической и патологической.
Физиологическая фрункциональная перестройка костной ткани характеризуется сбалансированно протекающими процессами разрушения кости (остеорезорбция) и костеобразования (остеогенез).

При фрункциональных перегрузках в одной или нескольких костях скелета могут развиться изменения, которые называются «патологической перестройкой» [4].

На основании многочисленных анатомических и экспериментальных исследований П. Ф. Лесгафт доказал, что двигательная фуункция является фрормообразующим и трофическим фактором за счет перестройки внутрикостной гемодинамиких и трофических процессов в кости.

Кости скелета снаружи покрыты периостом (за исключением суставных поверхностей). В периосте различают два слоя: наружный и внутренний. Наружный слой толстый, представлен плотной соединительной тканью, содержит коллагеновые волокна, кровеносные сосуды. В состав внутреннего (остеогенного) слоя надкостницы входят остеобласты, активно синтезирующие и секретирующие вещества костного матрикса. Пучки коллагеновых волокон направляются к кости и уходят из надкостницы в ее матрикс, что обеспечивает прочное прикрепление внутреннего слоя надкостницы.

Периост содержит остеогенные клетки, обеспечивающие развитие, рост и регенерацию костной ткани [5].

Периостит - воспаление надкостницы, которое может вызываться острыми или систематическими перенапряжениями ОДА. Воспалительный процесс чаще поражает участки костей, плохо защищенные мягкими тканями, например переднюю поверхность большеберцовой кости. Обычно он развивается во внутреннем или внешнем слое надкостницы.

Причинами периостита могут быть увеличение интенсивности и длительности тренировочных нагрузок, резкое изменение их направленности, изменение тренировочного покрытия, а также иметь травматическую природу. Такое состояние характерно для артистов балета, цирка, спортсменов с преимущественными нагрузками на нижние и верхние конечности.

Симптомы:

- развитие рабочей гипертрофрии кортикального слоя кости;

- локальная припухлость;

- возможна гиперемия в области повреждения;

- болезненность при движениях и пальпации $[13,16,18]$. 


\section{Повреждение костной ткани}

При несвоевременном лечении периостита процесс поражения с надкостницы распространяется на костную ткань вследствие их тесной структурной связи и начинается лакунарное (участками) рассасывание кости, что проявляется в виде зон Лоозера. В 1920 г. они впервые были описаны швейцарским хирургом и рентгенологом E. Looser, который обнаружил на рентгенограммах полосы просветления в отдельных участках кости в результате фризического перенапряжения участков скелета - на плюсневых костях, на длинных трубчатых костях нижних конечностей при выраженной их функциональной нагрузке [2, 13].

Зоны Лоозера возникают в участках наибольшего влияния механической нагрузки. Патологическая перестройка метаболических процессов в костной ткани может возникать у практически здоровых людей после длительных напряженных динамических нагрузок: у военнослужащих, особенно недостаточно фризически подготовленных к фрункциональным нагрузкам (марш-броски, кроссы по пересеченной местности, твердому покрытию); у спортсменов-стайеров после преодоления длинных дистанций, их частых повторений на тренировочных занятиях [25].

Изменения биомеханических условий функций ОДА вызывают состояние перенапряжения и нарушения морфоофункциональных характеристик кости, влияющих на ее прочность. Представление о биологическом утомлении костной ткани поддерживается многими специалистами в области ортопедии и травматологии $[2,3$, 13].

Функциональное перенапряжение костной ткани скелета может быть связано с утомлением мышц, которые теряют способность изменять распределение и уменьшать нагрузку на кость. Многие авторы считают, что основой возникновения патологической перестройки кости является усиленная локальная остеорезорбция остеокластами в участках наибольшего механического напряжения и замещение ее незрелой костной, волокнистой соединительной или хрящевой тканями $[4,12,20]$.

Широкое признание получила микротравматическая теория, свидетельствующая о том, что в зоне наибольшего механического напряжения возникают многочисленные переломы костных перекладин и пластин, вокруг которых фрормируется мозоль из остеоидной, волокнистой соединительной и хрящевой тканей для поддержания структурной целостности кости $[2,13]$.
При фрункциональном перенапряжении ОДА в участке наибольшего напряжения костной ткани нарушается кровообращение, развиваются трофические и структурные повреждения, приводящие к местной патологической перестройке кости с замещением нарушенного участка кости остеоидной или хрящевой тканью, при этом снижается ее прочность $[3,10]$.

Повреждение костной ткани при ее функциональном перенапряжении имеет множество названий. В отечественной литературе используются термины «патологическая перестройка» и «ползучий перелом», за рубежом однотипные повреждения называют «усталостный перелом», «стрессовый перелом» $[2,3]$.

Специалисты считают, что «патологическая перестройка» кости, «ползучий перелом» следует относить к профессиональной патологии, что важно для военной и спортивной медицины [4].

Спортивные травматологи, рентгенологи считают, что выраженное фризическое перенапряжение трубчатых костей, особенно нижних конечностей на ранних стадиях развития патологической перестройки начинается с периостального и эндостального костеобразования в виде локальных периостальных наслоений. Установлено, что этот процесс сопровождается усилением кровоснабжения периоста в участках функционального перенапряжения с формированием сосудистых анастомозов между сосудами периостата и костного мозга. Перераспределению крови на участке механического перенапряжения сопутствуют острые расстройства внутрикостного кровоснабжения, что приводит к дистрофии и некрозу костной ткани, активации ее резорбции. Рентгенологические показатели патологической перестройки кости в виде полосы просветления - зоны Лоозера - возникают позже, через 3-6 нед. Так, на рентгенограмме трубчатой кости появляется едва заметная полоса просветления с ровными краями в области диафиза, пересекающая его в поперечном направлении, иногда в косом [13].

Морфологическими исследованиями в первые часы после появления на рентгенограмме полосы просветления в поврежденном участке компактной кости на фоне формирующегося гиперостоза установлено, что в результате функционального перенапряжения возникает поперечная трещина - надлом. Если нагрузка на конечность продолжается, поперечная щель распространяется в поперечном направлении кости, что было названо «ползучим переломом» [2]. В зоне надлома в этот период (2-14 сут.) гистологически наблюдаются участки активной 
резорбции кости остеокластами и врастание в щель остеогенной ткани. В костной ткани по краям щели ползучего перелома усиливаются некротические изменения, увеличивается количество микротрещин. Резорбция костных краев приводит к неравномерному расширению щели, которая на протяжении 1-2 мес. почти полностью заполняется фиброзной или хрящевой тканью. Без надлежащего своевременного лечения постепенное распространение щели в поперечном направлении кости может привести к полному перелому кости.

Полные переломы, возникающие на фоне развивающегося гиперостоза при фризическом перенапряжении, отличаются от травматических переломов рядом особенностей: не сопровождаются либо сопровождаются небольшим смещением отломков кости; линия перелома в компактной кости чаще проходит в поперечном направлении [2, 13, 25].

Симптомы. На фоне периостита ползучий перелом проявляется остро на 2-3-ю неделю функционального перенапряжения. В анамнезе явные травмы, предшествующие появлению боли, отсутствуют. Спортсмены обычно обращаются к врачу, когда боль начинает ощущаться при тренировочном процессе либо при обычной ходьбе [9].

Лечение проводится в специализированном медицинском учреждении, где для уточнения диагноза проводят рентгенологическое обследование. Первичное появление полосы (щели) просветления поперечной диафизу направленности свидетельствует о ползучем переломе.

Для предотвращения возможного смещения фррагментов кости в зоне повреждения рекомендована иммобилизация гипсовой повязкой либо лонгетой.

Ползучие (усталостные) переломы нижних конечностей по механизму развития компрессионные, они редко прогрессируют до полного перелома и поэтому их лечение консервативное. При неэфроективном консервативном лечении показано оперативное вмешательство.

Прогноз возвращения в спорт после лечения ползучего перелома благоприятный, за исключением повреждений шейки бедренной кости, поскольку такие переломы чаще переходят в полный

\section{Литература}

1. Бенно М. Нигм. Чрезмерные нагрузки и механизмы спортивных травм // Спортивные травмы. Основные принципы профилактики и лечения / под ред. П.А.Ф.Х. Ренстрема. - К.: Олимп. лит., 2002. - С. 98-109. перелом со смещением костных отломков, что требует оперативного лечения [2, 12, 13].

\section{Профилактика ползучих переломов}

Чтобы предотвратить такие повреждения, следует:

- оптимизировать нагрузки в соответствии с функциональными возможностями спортсмена;

- исключить резкое увеличение фризической нагрузки;

- носить удобную спортивную обувь с супинаторами;

- ограничить (исключить) бег на длинные дистанции по жесткой поверхности;

- соблюдать рациональное питание;

- при появлении болей в области надкостницы (например, голени) постозности (припухлости) уменьшить повторение нагрузок высокой интенсивности либо изменить их направленность [9].

Выводы. По мнению А. Г. Дембо, Э. В. Земцовского [7], три основных человека определяют правильность и полноценность использования средств спорта - это спортивный врач, тренер, спортсмен.

Чтобы спорт выполнял свою оздоровительную фрункцию, допуск к занятиям спортом и медицинское наблюдение за спортсменами должен осуществлять высококвалифицированный, клинически грамотный, эрудированный спортивный врач, умеющий предупредить развитие болезни и лечить ее.

Чтобы тренировать спортсмена, не причиняя вред его здоровью, тренер должен быть широкоэрудированным, всесторонне образованным тренером-педагогом с большим запасом медикобиологических знаний, умеющий находить общий язык со спортивным врачом.

Спортсмен с самого начала спортивной деятельности должен знать сущность современной тренировки и спорта, основные условия, которые следует выполнять при тренировках с большими нагрузками, четко выполнять требования врача и тренера по соблюдению режима работы, отдыха, быть ознакомленным со всеми возможными отрицательными последствиями невыполнения этих требований.

\section{References}

1. Banno M. Nigm. Excessive loads and mechanisms of sports injuries // Sports injuries. Main principles of prevention and treatment ed. by P.A.F.H. Rensrem. - Kiev: Olimpiyskaya literatura, 2002. - P. 98-109. 
2. Бруско А. И. Функциональная перестройка костей и ее клиническое значение / А. И. Бруско, Г. В. Гайко. - Луганск, 2005. - 211 с.

3. Бруско А. Т. Механизм трофического влияния физических нагрузок на структурно-функциональную организацию костей / А. Т. Бруско, В. П. Омельчук, О. Г. Гайко // Пробл. остеопении. - 1998. - Т. 1, № 1. - С. 11-18.

4. Бруско А. Т. Функциональная перестройка кости в условиях перегрузки. Патологическая перестройка / А. Т. Бруско // Вестн. травматологии и ортопедии. 1996. - № 1. - С. 40-46.

5. Гистология: учеб. для студ. медвузов / под ред. проф. Э. Г. Улумбекова, проф. Ю. А. Челышева. - М.: ГЭОТАР, 2001. - С. 148-166.

6. Дембо А. Г. Актуальные проблемы современной спортивной медицины / А. Г. Дембо. - М.: Сов. спорт, 1980. - 295 с.

7. Дембо А. Г. Спортивная кардиология: рук. для врачей / А. Г. Дембо, Э. В. Земцовский. - Л.: Медицина, Ленингр. отд-ние, 1989. - С. 22-52.

8. Зайчик А.Ш. Общая патофизиология (с основами иммунологии): учеб. для мед. вузов / А.Ш. Зайчик, Л. П. Чурилов. - СПб.: ЭЛБИ, 2008. - С. 205-236.

9. Зеттерберг К. Повреждение костей / под общ. ред. П.А.Ф.Х. Ренстрема / К. Зеттерберг // Спортивные травмы. Основные принципы профилактики и лечения. - К.: Олимп. лит., 2002. - С. 42-51.

10. Ильин В. Н. Хроническое утомление в спорте - френомен или закономерность / В. Н. Ильин, М. М. Филиппов, А. Алвани // Спорт. медицина. - 2015. - №1-2. - С. 3-17.

11. Костная ткань у девочек и подростков, связь с половым и фризическим развитием / В.В. Поворознюк, И. Б. Вовк, Т. В. Орлик [и др.] // Захворювання кістковом'язової системи в людей різного віку (вибрані лекції, огляди, статті). - К., 2004. - Т. 2. - С. 27-61.

12. Левенець В. М. Синдром перевантаження - діагностика і лікування / В.М.Левенець // Спорт. медицина. - К., 2003. - № 1. - С. 32-36.

13. Левенець В. М. Ушкодження і захворювання п'яткового (ахіллового) сухожилля / В. М. Левенець, В. М. Майко, І. Б. Балюк. - К., 2010. - 216 с.

14. ЛеВенець В. М. Актуальні питання спортивного травматизму / В. М. Левенець // Спорт. медицина. 2004. - № 1/2. - C. 84-90.

15. Лоренс Риггз Б. Остеопороз. Этиология, диагностика, лечение / Риггз Б. Лоренс, Джозеф Л. Мелтон; пер. с англ. - М. ; СПб. : ЗАО «БИНОМ», «Невский диалект», 2000. - C. 471-504.

16. Макарова Г. А. Медицинский справочник тренера / Г. А. Макарова, С. А. Локтев. - М. : Сов. спорт, 2005. C. $397-415$.

17. Макарова Г. А. Переутомление и хроническое фризическое перенапряжение ведущих органов и систем организма спортсменов / Г. А. Макарова, Б. А. Поляев // Спортивная медицина: нац. рук. / под ред. С.П. Миронова, Б. А. Поляева, Г. А. Макаровой. - М.: ГЭОТАР-Медиа, 2012. - С. 876-900.

18. Макарова Г. А. Практическое руководство для спортивных врачей / Г. А. Макарова. - Ростов н/Д: БАРОПресс, 2002. - 796 с.

19. Макарова Г. А. Спортивная медицина: учебник / Г. А. Макарова. - М. : Сов. спорт, 2008. - С. 303-307.

20. Мак-Комас А. Дж. Скелетные мышцы / А. Дж. МакКомас. - К., 2001. - 406 с.

21. Мохан Рон. Биохимия мышечной деятельности и физической тренировки / Рон Мохан, Майкл Глессон, Пауль А. Гринхафрф. - К.: Олимп. лит., 2001. - 295 с.
2. Brusko A. I. Functional reorganization of bones and its clinical significance / A. I. Brusko, G. V. Chayko. - Lugansk, 2005. - $211 \mathrm{p}$

3. Brusko A. T. Mechanism of physical load trophic impact on bone structural and functional organization / A. T. Brusko, V. P. Omelchuk, O. G. Chayko // Problemy osteopeniyi. 1998. - Vol. 1, N 1. - P. 11-18.

4. Brusko A. T. Functional reorganization of bone under conditions of overstrain. Pathological reorganization / A. T. Brusko // Vestnik travmatologiyi i ortopediyi. 1996. - N 1. - P. 40-46.

5. Histology ed. by E. G. Ulumbekov, Y. A. Chelyshev: textbook for students of medical institutions. - Moscow: GEOTAR, 2001. - P. 148-166.

6. Dembo A. G. Actual problems of modern sports medicine / A. G. Dembo. - Moscow : Sov. sport, 1980. - 295 p.

7. Dembo A. G. Sports cardiology : manual for physicians / A. G. Dembo, E. V. Zemtsovsky. - Leningrad : Meditsina, 1989. - P. 22-52.

8. Zaychik A. S. General pathophysiology (with bases of immunology) : textbook for medical institutions / A. S. Zaychik, L. P. Churilov. - Saint Petersburg: ELBI, 2008. P. 205-236.

9. Zetterberg K. Bone injury [edited by P.A.F.H. Rensrem] / Karl Zetterberg / / Main principles of prevention and treatment. - Kiev: Olimpiyskaya literatura, 2002. - P. 42-51.

10. Ilyin V. N., Filipov M. M., Alvani A. Chronic fatigue in sport - phenomenon or regularity / V. N. Ilyin, M. M. Filipov, A. Alvani // Sportivnaya meditsina. - 2015. - N1-2. P. 3-17.

11. Osseous tissue in girls and adolescents, association with sexual and physical development / V. V. Povorozniuk, I. B. Vovk, T. V. Orlyk [et al.] // Diseases of skeletalmuscular system in people of different age. - Kyiv, 2004. Vol. 2. - P. 27-61.

12. Levenets V. M. Overexertion syndrome - diagnosis and treatment / V. M. Levenets // Sportyvna medytsyna. Kyiv, 2003. - N 1. - P. 32-36.

13. Levenets V. M. Achilles tendon injuries and diseases / V. M. Levenets, V. M. Mayko, I. B. Baliuk. - Kyiv, 2010. -216 p.

14. Levenets V. M. Actual issues of sports traumatism / V. M. Levenets // Sportyvna medytsyna. - 2004. - N 1/2. P. 84-90.

15. Lawrence Riggs B. Osteoporosis. Etiology, diagnosis, treatment / Riggs B. Lawrence, Joseph L. Melton ; translated from English. - Moscow ; Saint Petersburg: ZAO «BINOM», «Nevsky dialekt», 2000. - P. 471-504.

16. Makarova G. A. Medical manual of coach / G. A. Makarova, S. A. Loktev. - Moscow : Sov. sport, 2005. - P. 397-415.

17. Makarova G. A Over-fatigue and chronic physical overexertion of main organs and systems of athlete body / G. A. Makarova, B. A. Polyayev // Sportivnaya meditsina / ed. by S. P. Mironov, B. A. Polyayev, G. A. Makarova. Moscow : GEOTAP-Media, 2012. - P. 876-900.

18. Makarova G. A Practical guide for sports physicians / G. A. Makarova. - Rostov-on-Don : BARO-Press, 2002. -796 p.

19. Makarova G. A Sports medicine : textbook / G. A. Makarova. - Moscow : Sov. sport, 2008. - P. 303-307.

20. McComas A. J. Skeletal muscles / A. J. McComas. Kiev, 2001. - 406 p.

21. Maughem Ron. Biochemistry of muscular activity and physical training / Pon Maughem, Mikhail Glesson, Paul A. Grinhaff. - Kiev: Olimpiyskaya literatura, 2001. - 295 p. 
22. Платонов В. Н. Система подготовки спортсменов в Олимпийском спорте. Общая теория и ее практические приложения: учебник / В. Н. Платонов. - К.: Олимп. лит., 2004. - С. 220-229, С. 674-693.

23. ПлатоноВ В. Н. Травматизм в спорте, проблемы и перспективы их решения / В. Н. Платонов // Спорт. медицина. - 2006. - № 1. - С. 54-77.

24. Подрушняк Е. П. Остеопороз - проблема века / Е. П. Подрушняк. - Симферополь: Одиссей, 1997. - 216 с.

25. ПолежаеВ В. Г. Стрессовые переломы / В. Г. Полежаев, И. С. Савка, В. И. Чобан. - К.: Феникс, 2003. - 160 с.

26. Руководство по спортивной медицине /под ред. В. А. Маргазина. - СПб.: СпецЛит., 2012. - С. 215-222.

27. Смолевский В. М. Спортивная гимнастика В. М. Смолевский, Ю. К. Гавердовский. - К.: Олимп. лит., 1999. - С. 451-456.

28. Физическое перенапряжение у спортсменов: метод. рек. / А. М. Алавердян, Б. Р. Альперович, В. В. Городецкий [и др.]. - М., 1987. - 41 с.

29. Фольборт Г. В. Избранные труды / Г. В. Фольборт. - К., 1962. - С. 40.

30. Ярвинен Маркку. Повреждение мышц / под общ. ред. П. А. Ф. Х. Ренстрема / Маркку Ярвинен // Спортивные травмы. Клиническая практика, предупреждение и лечение. - К.: Олимп. лит., 2003. - С. 93-101.

31. Kham K. M. Where on the pain coming in tendinopathy? It may by biochemical, not only structural, in origin / K. M. Kham, I. Cook, N. Maffuli // Br. J. Sports Med. 2000. - N 34. - P. 81-84.

32. Microcirculation of the ankle after Crio Cuff application in healthy volunteers / K. Knobloch, R. Kraemer, A. Lichtenberg [et al.] // J. Sports Med. - 2006. - N 27. P. 250-255.
22. Platonov V. N. System of athletes' preparation in the Olympic sport. General theory and its practical applications: textbook / V. N. Platonov. - Kiev: Olimpiyskaya literatura, 2004. - P. 220-229, P. 674-693.

23. Platonov V. N. Traumatism in sport, problems and perspectives of their solution / V. N. Platonov // Sportyvnaya meditsina. - 2006. - N 1. - P. 54-77.

24. Podrushnyak E. P. Osteoporosis - problem of the century / E. P. Podrushnyak. - Simferopol: Odissey, 1997. - 216 p.

25. Polezhayev V. G. Stress fractures / V. G. Polezhayev, I. S. Savka, V. I. Choban. - Kiev: Feniks, 2003. - 160 p.

26. Sports medicine handbook [ed. by V. A. Margazin]. Saint Petersburg SpetsLit., 2012. - P. 215-222.

27. Smolevsky V. M. Artistic gymnastics / V. M. Smolevsky, Y. K. Gaverdovsky. - Kiev: Olimpiyskaya literatura, 1999. - P. 451-456.

28. Physical overexertion in athletes: [methodical recommendations] / A. M. Alaverdyan, B. R. Alperovich, V. V. Gorodetsky [et al.]. - Moscow, 1987. - 41 p.

29. Folbort G. V. Elected works / G. V. Folbort. - Kiev, 1962. - P. 40.

30. Jarvinen Markku. Muscle injuries / ed. by P.A.F.H. Rensrem / Markku Jarvinen // Sports injuries. Main principles of prevention and treatment. - Kiev: Olimpiyskaya literatura., 2003. - P. 93-101.

31. Kham K.M. Where on the pain coming in tendinopathy? It may by biochemical, not only structural, in origin / K.M. Kham, I. Cook, N. Maffuli // Br. J. Sports Med. 2000. - N 34. - P. 81-84.

32. Microcirculation of the ankle after Crio Cuff application in healthy volunteers / K. Knobloch, R. Kraemer, A. Lichtenberg [et al.] // J. Sports Med. - 2006. - N 27. P. 250-255. 